\title{
The Holistic View of the Symptoms of Financial Health of Businesses
}

\author{
Lucia Michalkova $^{\mathrm{a} *}$, Katarina Valaskova ${ }^{\mathrm{b}}$, Katarina \\ Frajtova Michalikova ${ }^{c}$ \\ Faculty of Operation and Economics of Transport and \\ Communications \\ University of Zilina \\ Zilina, the Slovak Republic \\ a lucia.michalkova@fpedas.uniza.sk \\ b katarina.valaskova@fpedas.uniza.sk \\ c fmichalikova@fpedas.uniza.sk
}

\author{
Andrea Drugau-Constantin \\ Faculty of Administration and Public Management \\ Bucharest University of Economic Studies \\ Bucharest, Romania \\ andreeadrugau@gmail.com
}

\begin{abstract}
Each phase of an enterprise's life cycle brings different impacts on corporate financial health. Financial distress may be associated with the emergence of a crisis, failure and / or bankruptcy. To identify these negative corporate phenomena timely, you need to know the appropriate symptoms. These symptoms occur in every business, but not every business can detect and evaluate them properly. The detection of symptoms of a change in corporate health depends on the definition of financial distress. The aim of the paper is to reveal an overall view of the symptoms of a financially sound business and, on the contrary, the symptoms of its deterioration by analyzing various definitions of financial distress. We analyzed, compared, and summarized the main symptoms of the company's financial health. We found that the main symptoms of a deterioration in financial health include negative cash flow, operational and / or overall losses, high indebtedness and insolvency. On the other hand, we have found that, in addition to traditional financial indicators, other symptoms of financial health, such as market share, stock value, or redundancy, should be examined.
\end{abstract}

Keywords-Bussiness failure; Insolvency; Bankruptcy; Financial health

\section{INTRODUCTION}

There could be a variety of situations in the life cycle of each business, some of which are connected with success and prosperity, others - with crisis, failure and bankruptcy. It is clear that the objective of managing each business is to be in the first type of these situations, in fact, however, the second type also cannot be excluded because crisis and critical situations are the activators of every market economy [1]. While during business growth the company improves gradually and to some extent without major steps taken by management, in times of crisis radical and often unwelcome steps are necessary in order to re-establish financial health and gain business stability [2-4].

The crisis can, therefore, create room for radical change, i.e. it is an analogy of natural selection in nature, when only strong individuals survive and adapt to new conditions and others may become extinct. Therefore, each enterprise should be at least theoretically ready for the last phase of its life cycle, i. e. for a situation where, for example, it will not be able to meet its obligations [5]. This situation almost never comes unexpectedly and without warning, on the basis of financial analysis the company's management must be able to identify threatening problems [6, 7]. Issue of predicting financial health of companies should become a centre of interest for the broad group of professionals but also for lay public.

\section{SYMPTOMS OF FINANCIAL HEALTH}

In detecting the symptoms of deteriorating business financial health or the symptoms of business failure we will begin with the pioneer in this prediction field, E. I. Altman [8], who summarized this issue into five categories or general terms:

- economic failure means that the projected return on investment capital, taking into account the risk, is significantly and consistently lower than prevailing returns on this type of investments;

- business failure is characterized by a stop of operations or bankruptcy, execution, confiscation of assets, merger, voluntary resignation from unpaid obligations or legal action.

- technical insolvency occurs when a firm fails to meet its existing obligations due to lack of cash flow.

- insolvency is a more critical and more chronic condition in which the firm's overall liabilities exceed the market value of total company assets

- bankruptcy means a formal declaration of bankruptcy by legal means, either in order to liquidate the assets of a company or to attempt a recovery program.

Fitzpatrick [9] was one of the first to define financial distress. According to him, the financial distress is the company's inability to repay its financial obligations after their maturity. Beaver [10] pointed out that financial distress can manifest itself in various forms depending on the type of event that occurred - bankruptcy, unsecured bond, bank overdraft or non-payment of priority share dividend.

Andrade and Kaplan [11] Baldwin and Mason [12] and Brown, et al. [13] refer to similar definitions of financial 
distress. These authors interpret financial distress as a decisive event, the occurrence of which separates the period of company's financial health from the time of financial illness and requires the implementation of corrective actions in order to overcome problematic situations. Andrade and Kaplan identify two forms of financial distress: the first is focused on paying off debt and the second is an attempt to restructure the debt in order to avoid the worsening of the situation. Brown, at al. classify companies in financial distress according to whether they will implement restructuring measures in order to avoid insolvency or as a response to the alleged inability to repay debts.

Whitaker [14] criticizes the definition of financial distress as a onetime event. He claims that insolvency cannot be defined as a synonym for financial distress because the company bears many losses and other adverse effects at the time before insolvency or bankruptcy.

Opler and Titman [15] define financial distress as a term that is broader than only cost-related problem and that affects the relationship between fund providers (creditors) and nonfinancial sides and participants. As a result, the company tries to gain influence on access to new capital and carries the rising costs of maintaining this dependent relationship. Gestel et al. [16] characterize financial distress and failure as a result of chronic losses that cause disproportionate increases in liabilities accompanied by loss of assets. Hendel [17] uses a probable definition of financial distress as "the likelihood of bankruptcy, which depends on the level of liquid assets as well as on the availability of credit or loans".

Gordon [18] emphasizes that financial distress is just one step in the process, followed by failure and restructuring, and should be defined in terms of financial structure and security measures. The company enters into this state when its ability to generate profits becomes weaker and the amount of debt exceeds the value of the company's total assets.

Purnanandam [19] defines financial distress when solvency is described. He develops the theoretical model of risk management for the company in consideration of the cost of financial distress. Financial distress is seen by him as a transitory stage between solvency and insolvency. The company is in a state of distress when it misses interest payments or does not keep loan agreements. Transformation from a state of solvency to insolvency occurs only on the due date if the present value of an enterprise's assets is less than the nominal value of the debt [20].

Pindado and Rodrigues [21] characterize financial distress quite briefly but comprehensively, according to them an enterprise may be in a state of distress without insolvency. However, insolvency and bankruptcy are not possible without a prior period of financial distress. The authors also define and emphasize the legal as well as the rather strategic aspect of bankruptcy nature.

In his study Gilbert et al. [22] show that financial distress has different financial characteristics than bankruptcy. Financial distress is characterized by a negative cumulative income for at least several consecutive years, losses and poor performance. The bankruptcy is one of possible outcomes of financial distress. A firm in financial distress has the opportunity to restructure its debt and to achieve a reasonable level of solvency, or to merge, thereby ceasing to exist as an independent business entity, or to file a bankruptcy petition as a strategic response of management or owners to financial problems.

The notion that financial distress is a separate economic category was used in the model by the authors Turetsky and McEwen [23]. Financial distress is defined as a series of interconnected stages characterized by a particular set of unfavourable financial operations. Each phase of financial distress has an emergency point and continues until another emergency point is reached. Technically, each stage of financial distress is defined as the interval between two emergency points. Financial distress starts with an essential decline from positive to negative cash flow. The following decrease in dividends signals a change to the next stage leading to insolvency. Failure to repay debt precedes debt restructuring which has a tendency to reduce the risk of bankruptcy [24, 25].

The most important signals of financial difficulties can be obtained from an analysis of the company's financial indicators. Accounting based on financial distress indicators is still actively used among researchers and widely used as a selection criterion. Despite the criticism that the financial indicators are past-oriented and cannot capture the future development and prospects of the company as an ongoing process, these indicators are well-proven in models predicting financial distress and probability of failure.

The deterioration of the financial health of the company on three levels or dimensions defined by Richter [26] are as follows:

- economic distress: after taking into account the market values while considering that the business continues its operations, the company's own equity is negative,

- financial distress: the net present value of the expected business cash flows is positive but does not exceed the amount of all liabilities. An enterprise is unable to pay all its current and future debts even after taking into account future positive cash flows,

- liquidity distress: the net present value of expected cash flows from business activities exceeds the amount of all liabilities. An enterprise is unable to pay its due liabilities at a given time. This business does not experience failure but it can reach it if it does get a delay in paying its liabilities or it does not receive liquid funds,

Denis and Denis [27] identifies financial distress as negative operating income or net pre-tax profit for at least three consecutive years. From the results of the empirical analysis of dividend policy during financial distress, they conclude that after financial distress starts to occur, the company is typically experiencing cash flow problems and is unable to pay dividends. For this reason, a quick and aggressive reduction of dividends along with the following negative earnings can be used to determine the level of financial distress. 
Goldson [28] presents a partly quantitative view of financial distress and lists the symptoms of financial distress as a decline in operating profit of 5\% per annum, a year-on-year decline in market share, quality managers departure to competitors, declining levels of financial performance, decrease of the ability to generate cash, increase in inventory of finished goods, reduction of $\mathrm{R} \& \mathrm{D}$ expenditure, cannibalization of the company's new products on the market, production capacity is at the level of $60 \%$ and the company has a contract volume of production less than $10 \%$ of annual planned production.

Asquith et al. [29] chose the interest coverage ratio for defining financial distress. A firm is classified as being in distress if in any of the two consecutive years its EBITDA is less than $80 \%$ of the company's interest expense. This indicator includes the fact that an enterprise experiencing financial distress typically experiences a decline in profitability, is indebted or does not have sufficient cash flows to cover current liabilities.

Platt and Platt [30] highlight the lack of a uniform definition of the situation when an enterprise enters financial distress and attempts to summarize various operational definitions of financial distress in one way. An enterprise is considered to be in financial distress if one of the following events occurs: it has been experiencing several years of negative net operating revenues or a suspension of dividend payments, financial restructuring or massive layoffs take place.

As symptoms of financial distress the authors of Balcaen and Ooghe [31] report: operational losses or total income losses continuing for a certain period of time, non-payment of priority dividends, non-fulfilment of bond obligations, extensive lay-offs, restructuring of capital, accumulation of losses and negative cash flow.

In order to identify financial distress, they very often use both accounting and market factors. This mixed approach allows to capture the complex and heterogeneous nature of the distress phenomenon linking its endogenous and exogenous factors. Opler and Titman [15] use median revenue growth and median returns on shares to identify troubled businesses. Negative returns on shares (down below -30\%) indicate the unexpected nature of undesirable processes occurring in the business. In addition to negative revenue growth, negative returns on shares indicate the existence of hidden business operating problems. These two indicators are especially important in times of economic downturn, as they reflect not only the effective capital structure of an enterprise, but also its dependence on the investors' mood and the position of competitors.

According to Baker and Powell [32], financial distress occurs when a company has problems with fulfilling contractual obligations associated with debt financing. This is a general weakening of the financial condition of a business due to its enormous debt, while the extreme case of financial distress is bankruptcy.

Whitaker [14] uses the cash flow ratio and market value ratio of an enterprise to identify when it enters financial distress. Financial distress is defined as a situation where an enterprise does not have sufficient cash flows to cover its liabilities and a decline in its market value occurs.

At the end we would like to mention a definition of financial distress by Hopwood et al. [33] who classify selected businesses according to whether they are exposed to at least one of the following financial distress signals: negative working capital in the current year, loss of operations in any of the three years prior to bankruptcy (failure), deficit of retained earnings in the year 3 (where the year 1 is the last before the date of financial statement prior to the bankruptcy) or the lower limit of the loss in any of the last three years before the bankruptcy.

\section{RESUlTS AND DisCUSSION}

Overall, we summarize the definitions of financial stress mentioned above and create a clear list of signs of deterioration in financial health as outlined in Table I.

TABLE I. COMPREHENSIVE VIEW OF THE SYMPTOMS OF FINANCIAL DISTRESS

\begin{tabular}{|c|c|}
\hline Symptom & Source \\
\hline $\begin{array}{l}\text { Non-payment } \\
\text { dividend/decline of the } \\
\text { value }\end{array}$ & $\begin{array}{l}\text { Beaver [10], Turetsky and McEwen } \\
\text { [23], Denis and Denis [27], Platt and } \\
\text { Platt [30], Balcaen and Ooghe [31] }\end{array}$ \\
\hline Insolvency & $\begin{array}{l}\text { Whitaker [14], Turetsky and McEwén } \\
\text { [23] }\end{array}$ \\
\hline $\begin{array}{l}\text { Value of debt less than } \\
\text { value of assets }\end{array}$ & $\begin{array}{l}\text { Gestel et al. [22], Gordon [18], } \\
\text { Purnanandam [19], }\end{array}$ \\
\hline $\begin{array}{l}\text { Negative cash flow/decline } \\
\text { of the value }\end{array}$ & $\begin{array}{l}\text { Whitaker [14], Turetsky and McEwen } \\
\text { [23], Richter [26], Goldson [28] }\end{array}$ \\
\hline $\begin{array}{l}\text { Operational losses/decline } \\
\text { of the profit }\end{array}$ & $\begin{array}{l}\text { Opler and Titman [15\, Goldson [28], } \\
\text { Platt and Platt [30], Balcaen and Ooghe } \\
\text { [31], Hoopwood et al. [33], Denis and } \\
\text { Denis [27] }\end{array}$ \\
\hline $\begin{array}{l}\text { Total losses/decline of the } \\
\text { profit }\end{array}$ & $\begin{array}{l}\text { Gilbert et al. [22], Balcaen and Ooghe } \\
\text { [31] }\end{array}$ \\
\hline Poor financial performance & Gilbert et al. [22], Goldson [28] \\
\hline $\begin{array}{l}\text { Breach the terms of debt } \\
\text { agreement }\end{array}$ & $\begin{array}{l}\text { Purnanandam [19], Baker and Powell } \\
\text { [32] }\end{array}$ \\
\hline $\begin{array}{lcr}\text { Unsecured } & \text { bond/ } & \text { non- } \\
\text { fulfilment } & \text { of } & \text { bond } \\
\text { obligations } & & \end{array}$ & Beaver [10], Balcaen and Ooghe [31], \\
\hline $\begin{array}{l}\text { High leverage and interest } \\
\text { charges }\end{array}$ & $\begin{array}{l}\text { Opler and Titman [15], Asquith et al. } \\
\text { [29] }\end{array}$ \\
\hline $\begin{array}{l}\text { Operational management } \\
\text { issues }\end{array}$ & Goldson [28], Hoopwood et al. [33] \\
\hline Employees quit/layoff & Goldson [28], Balcaen and Ooghe [31] \\
\hline Decline of market value & Opler and Titman [15], Goldson [28] \\
\hline
\end{tabular}

Based on the analysis of the definition of financial distress mentioned above, the main symptoms of financial distress is worsening financial performance in terms of high debt, operating and / or total losses and / or negative cash flow. On the other hand, other factors affecting the company's financial health, such as market share, inventory status, working capital or changes in employee numbers, need to be examined.

Financial indicators are the most frequently studied symptoms of financial health worsening. These quantitative variables have a significant impact on financial health, but they are only secondary symptoms of a change in financial performance. It should be noted that it is the lesser known quality indicators, such as low R \& D spending or obsolete 
products can be sufficiently early signal of future state of financial distress. For this reason, an enterprise should explore a wider range of financial health indicators as cited by the authors; it is necessary to develop a suitable methodology for early detection of symptoms of future defaults.

The symptoms of financial distress are also often used as variables in bankruptcy prediction model. Traditional financial ratios such as interest coverage ratio, leverage ratio, current ratio and return on assets can be easily implemented into a mathematical prediction model. Nevertheless, such models may have less predictive power due to the non-inclusion of relevant variables such as the market share or the low percentage of contracted production compared to the total planned output. The lack of such indicators is often the absence of factor quantification, which is necessary for implementation into traditional statistical prediction models. The way out of this situation is to use non-traditional methods of prediction of financial health such as multi-criteria decision aid approach.

Based on the review, summarization and comparison of financial health symptoms we can be stated that at present is still greater emphasis on financial indicators; qualitative indicators are not sufficiently examined. For this reason, we will see future research in this area in developing an adequate methodology for the comprehensive disclosure of the symptoms of future deterioration in financial health. On the other hand, qualitative indicators may be difficult to apply to traditional prediction models. At the same time, it is not possible to create the methodology in general because each sector has its own specificities that would make the methodology cumbersome. For this reason, the analysis of the symptoms of financial health has a wide range of issues that can be examined.

\section{CONCLUSION}

Symptoms of financial distress never occur at the same time, but in certain phases. First there is a decrease in output volume, a decrease in profitability, an increased need for working capital, a deterioration of the capital structure and finally it comes to a persistent insolvency [34, 35].

For a brief summary we would like to state that different approaches to defining the term "financial distress" or "financial health of the company" show how complex and sometimes even controversial this economic category is [36]. The current state of the theory of financial distress rather explains this phenomenon depending on the purpose of research according to a certain aspect: financial, operational, legal, etc., which leads to the use of this term interchangeably with other similar financial definitions [37].

The theory of financial distress, full of specific mechanisms and anomalies, still needs consolidation and an agreement on the uniform formal application of equivalent economic criteria. A modern approach should interpret financial distress as a heterogeneous and dynamic process with different characteristics that evoke various economic signals. In this paper, we analyzed, compared, and summarized the main symptoms of the company's financial health. On the basis of the induction, we found that the main symptoms of a deterioration in financial health include negative cash flow, operational and / or overall losses, high indebtedness and insolvency. On the other hand, we have found that, in addition to traditional financial indicators, other symptoms of financial health, such as market share, stock value, or redundancy, should be examined.

\section{ACKNOWLEDGMENT}

The paper is an output of the science project VEGA 1/0428/17 Creation of new paradigms of financial management at the threshold of the $21^{\text {st }}$ century in conditions of the Slovak Republic.

\section{REFERENCES}

[1] T. Kliestik, M. Misankova, K. Valaskova, and L. Svabova, "Bankruptcy prevention: new effort to reflect on legal and social changes," Science and Engineering Ethics, vol. 24(2), pp. 791-803, 2018.

[2] M. Kovacova and T. Klieštik, "Logit and Probit application for the prediction of bankruptcy in Slovak companies," Equilibrium. Quarterly Journal of Economics and Economic Policy, vol. 12(4), pp. 775-791, 2017.

[3] B. Gavurova, M. Packova, M. Misankova, and L. Smrcka, "Predictive potential and risks of selected bankruptcy prediction models in the Slovak business environment," Journal of Business Economics and Management, vol. 18(6), pp. 1156-1173, 2017.

[4] J. Kliestikova, M. Misankova, and T. Kliestik, "Bankruptcy in Slovakia: international comparison of the creditor's position," Oeconomia Copernicana, vol. 8(2), pp. 221-237, 2017.

[5] T. Kliestik and J. Majerova, "Selected issues of selection of significant variables in the prediction models," Proceedings of 10th international scientific conference: Financial management of firms and financial institutions, part II, pp. 537-543, 2015.

[6] M. Radisic and D. Dobromirov, "Statistical analysis of price returns of regional stock market indices," Transformations in Business \& Economics, vol. 16, no. 3 (42), pp. 175-184, 2017.

[7] R.. Sadaf, J. Olah,, J. Popp, and D. Mate, "An investigation of the influence of the worldwide governance and competitiveness on accounting fraud cases: A cross-country perspective," Sustainability, vol. 10, no. 3(588), 2018, available at: https://www.mdpi.com/2071$1050 / 10 / 3 / 588$.

[8] E.I. Altman, Corporate Financial Distress and Bankruptcy. 2nd ed. NewYork : John Wiley and Sons, 1993.

[9] P.J. FitzPatrick, "A Comparison of the Ratios of Successful Industrial Enterprises With Those of Failed Companies," The Certified Public Accountant, 1932.

[10] W. Beaver, "Financial Ratios as Predictors of Failure," Journal of Accounting Research, vol. 4(3), pp. 71-111, 1966.

[11] G. Andrade and S.N. Kaplan, "How Costly is Financial (not Economic). Distress? Evidence from Highly Leveraged Transactions that Become Distressed," Journal of Finance, vol. 53(5), pp. 1443-1494, 1988.

[12] C.Y. Baldwin and S.P. Mason, "The Resolution of Claims in Financial Distress the Case of Massey Ferguson," The Journal of Finance, vol. 38(2), pp. 505-516, 1983.

[13] D.T. Brown, C.M. James, and R.M. Mooradian, "The Information Content of Distressed Restructurings Involving Public and Private Debt Claims," Journal of Financial Economics, vol.33, pp. 93-118, 1993.

[14] R. Whitaker, "The Early Stages of Financial Distress," Journal of Economics and Finance, vol. 23(2), pp. 123-133, 1999.

[15] T. Opler and S. Titman, "Financial Distress and Corporate Performance. In: The Journal of Finance, “ vol. 49(3), pp. 1015-1040, 1994.

[16] T. Gestel, B. Baesens, J.S.K. Suykens, D. Van den Poel, D.-E. Baestaens, and M. Willekens "Bayesian Kernel Based Classification for Financial Distress Detection," European Journal of Operational Research, vol. 172(3), pp. 979-1003, 2006.

[17] I. Hendel, "Competition under Financial Distress. In: The Journal of Industrial Economics," vol.54(3), pp. 309-324, 1996. 
[18] M.J. Gordon, "Towards a Theory of Financial Distress," The Journal of Finance, vol. 26(2), pp. 347-356, 1971.

[19] A. Purnanandam, "Financial Distress and Corporate Risk Management: Theory \& Evidence," Working Paper, Ross School of Business, University of Michigan, 2005.

[20] A.P. Balcerzak, T. Kliestik, D. Streimikiene, and L. Smrcka, "NonParametric Approach to Measuring the Efficiency of Banking Sectors in European Union Countries," Acta Polytechnica Hungarica, vol. 14(7), pp. 51-70, 2017.

[21] J. Pindado and L. Rodrigues, "Parsimonious Models of Financial Insolvency in Small Companies," Small Business Economics”, vol. 22, pp. 51-66, 2004

[22] L.R. Gilbert, K. Menon, and K.B. Schwartz, "Predicting Bankruptcy for Firms in Financial Distress," Journal of Business Finance and Accounting, vol. 17, pp. 161-171, 1990.

[23] H.F. Turetsky and R.A. McEwen, "An Empirical Investigation of Firm Longevity: A Model of the Ex Ante Predictors of Financial Distress," Review of Quantitative Finance and Accounting, vol. 16(4), pp. 323343, 2001.

[24] E. Madudova, "The importance of supporting the business activities of creative industries," Ekonomicko-manazerske spektrum, vol. 11(1), pp. 37-47, 2017.

[25] E. Shadrina, "Russia's Oil and Gas for Northeast Asian Markets: Means and Ways vs Realities," Journal of Self-Governance and Management Economics, vol. 5(1), pp. 34-79, 2017.

[26] T. Richter, Insolvencni pravo, Praha: ASPI-Wolters Kluwer, 2008.

[27] D. Denis and D. Denis, "Causes of Financial Distress Following Leveraged Recapitalizations," Journal of Financial Economics, vol 37(2), pp. 129-158, 1995
[28] M. Goldson, The turnaround prescription, New York: Macmilan, 1992.

[29] P. Asquith, R. Gertner, and D. Scharfstein, "Anatomy of Financial Distress: An Explanation of Junk Bond Issuers," The Quarterly Journal of Economics, vol. 109, pp. 625-658, 1994.

[30] H. Platt and M. Platt, "Predicting Corporate Financial Distress: Reflections on Choice-Based Sample Bias," Journal of Economics and Finance, vol. 26(2), pp. 184-199, 2002.

[31] S. Balcaen and H. Ooghe, "35 years of studies on business failure: an overview of the classic statistical methodologies and their related problems," The British Accounting Review, vol. 38(1), pp. 63-93, 2006.

[32] H.K. Baker and G.E. Powel, Understanding Financial Management, Malden: Blackwell Publishing, 2005.

[33] W. Hopwood, J.C. McKeown, and J.F.Mutchler, "A reexamination of Auditor versus Model Accuracy Within the Context of the GoingConcern Opinion Decision," Contemporary Accounting Research, vol. 10, pp. 409-431, 1994.

[34] S.J. Silverman, and B. Lewis, "Families in US Immigration Detention: What Does It Mean to Do 'the Right Thing'?" Contemporary Readings in Law and Social Justice, vol. 9(2), pp. 95-115, 2017.

[35] D. Rowlands and D.K. Kabongi, "Military Expenditures, Alliance Membership, and Fiscal Restraint," Geopolitics, History, and International Relations, vol. 9(2), pp. 55-79, 2017.

[36] G. Lazaroiu and D. Rommer, "Digital technologies, labor markets, and economic reputation," Ekonomicko-manazerske spektrum, vol. 11(2), pp 13-21, 2017.

[37] D. Moravcikova, A. Krizanova, J. Kliestikova, and M. Rypakova, "Green marketing as the source of the competitive advantage of the business," Sustainability, vol. 9(12), 2017, available at: www.mdpi.com/2071-1050/9/12/2218/pdf. 